\title{
THE EFFECT OF ABIOTIC FACTORS ON THE HATCHING OF Moina micrura KURZ, 1874 (CRUSTACEA: CLADOCERA) EPHIPPIAL EGGS
}

\author{
ROJAS, N. E. T., ${ }^{1}$ MARINS, M. A. ${ }^{2}$ and ROCHA, O. ${ }^{2}$ \\ ${ }^{1}$ Centro de Pesquisa em Reprodução e Larvicultura, Instituto de Pesca, São Paulo, SP, Brazil \\ ${ }^{2}$ Departamento de Ecologia e Biologia Evolutiva, Universidade Federal de São Carlos, Rodovia Washington \\ Luiz, km 235, CEP 13565-905, São Carlos, SP, Brazil \\ Correspondence to: Nilton Eduardo Torres Rojas, Instituto de Pesca, Av. Francisco Matarazzo, 455, \\ CEP 05001-900, São Paulo, SP, Brazil, e-mail: niltonrojas@uol.com.br \\ Received January 21, 2000 - Accepted March 8, 2000 - Distributed August 31, 2001
}

(With 2 figures)

\begin{abstract}
The roles of some abiotic factors in controlling the hatching rates of Moina micrura ephippial eggs were investigated. Determination of optimum hatching conditions would be important in developing the use of this species as a food for fish larvae in aquaculture. Ephippia were exposed to different treatments in the laboratory, and monitored for hatching over a period of seven days. Optimum hatching

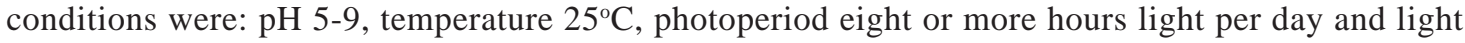
intensity equal to or greater than 850 lux. Differences in water ionic concentrations (from deionized water to $880 \mathrm{mg} . \mathrm{L}^{-1}$ of selected salts) had no effect.
\end{abstract}

Key words: Moina micrura, ephippia, encysted embryos, abiotic factors, egg hatching.

\section{RESUMO}

\section{Influência de fatores abióticos na eclosão dos ovos efipiais de Moina micrura Kurz, 1874 (Crustacea: Cladocera)}

Foram investigados os efeitos de alguns fatores abióticos na taxa de eclosão dos ovos efipiais de Moina micrura. O conhecimento das melhores condições para a eclosão desses ovos pode ser importante na utilização dessa espécie para a aqüicultura, como alimento para larvas de peixes. Os efípios foram expostos a diferentes experimentos em laboratório por um período de sete dias. As melhores condições de eclosão foram: $\mathrm{pH}$ de 5 a 9 , temperatura de $25^{\circ} \mathrm{C}$, fotoperíodo de oito ou mais horas de luz e intensidade luminosa igual ou maior que 850 lux. Diferentes concentrações de íons na água (de água deionizada e até $880 \mathrm{mg} \cdot \mathrm{L}^{-1}$ de sais selecionados) não influenciaram a eclosão.

Palavras-chave: Moina micrura, efípio, embriões encistados, fatores abióticos, eclosão de ovos.

\section{INTRODUCTION}

Many zooplankton taxa produce encysted embryos, usually resulting from sexual reproduction. Such resting stages form a key part of aquaculture, and the mastering of both acquisition and hatching techniques of such cysts and ephippia is crucial for larviculture of fish and crustaceans.

Moina micrura is a common species found throughout South America. Zaniboni Filho (1992) and Fregadolli (1993) have found that this genus is important as food for fish larvae, such as pacu (Piaractus mesopotamicus) and tambaqui (Colossoma macropomum), which are commonly utilized in Brazilian aquaculture. The factors involving the induction of development and hatching of dormant eggs in the genus Moina are not known (Rojas, 1995). The goal of this work was to examine the relationship between $\mathrm{pH}$, concentration of dissolved ions, temperature, photoperiod and light inten- 
sity (environmental features found to effect the hatching rates of other crustaceans - Stross, 1966; Davison, 1969; Sorgeloos et al., 1986) and the hatching of Moina micrura ephippial eggs, in an effort to define optimum hatching techniques. This would serve as a departure point for the culture and/or use of neonates of $M$. micrura for feeding fish larvae.

\section{MATERIAL AND METHODS}

For full details on the materials and methods employed, see Rojas (1995).

Cladocera were collected in fish ponds in Pindamonhangaba (22 $55^{\prime}$ '55'S; 45²7’02”W), São Paulo, Brazil.

From 1992 to 1994, populations were kept in laboratory aquaria with 30-40 L of water (maintained at a temperature of $25 \pm 2^{\circ} \mathrm{C}$, with a photoperiod of 14 hours light at an intensity of 500 lux). Two-thirds of the water were renewed every week. The replacing water came from an outdoor fibro-cement tank (capacity 1,000 L), containing water plants (Elodea sp.) and fish (Poecilia sp.).

The water level of this tank was maintained mostly by rain water. Before being used in the cultures, the water was filtered through a $30 \mu \mathrm{m}$ plankton net, and aerated for 24 hours. The Moina were fed " ad libitum" twice a day, in the morning with Baker's yeast (Saccharomyces cerevisiae) and, at the end of the afternoon, with algae (Chlorella homosphaera, Scenedesmus ecornis, Kirchneriella lunaris, Chlamydomonas sp. and Nephrocylium lunatium), cultured in W.C. medium (Guillard \& Lorenzen, 1972). The latter were harvested during the exponential growth phase, centrifuged and resuspended before being used.

Production of ephippia was apparently spontaneous. Every week, the bottoms of the culture containers were checked and, upon finding a sufficient number of ephippia, these were siphoned off and kept in water at a temperature of $5 \pm 1^{\circ} \mathrm{C}$. Following a minimum period of 15 days, the eggs were checked for the occurrence of hatching (loss of dormancy) and then used in the tests.

The experiments, lasting for 7 days, were carried out in beakers $(100 \mathrm{ml})$ with $50 \mathrm{ml}$ of water. A mixture of biologically filtered and distilled water (1:1), previously aerated for 12 hours, was used in experiments 1, 3, 4 and 5. For experiment 2 , deionized water was used. During the experiments, the water was not replaced. $\mathrm{pH}$ and conductivity correction and/or monitoring were directly performed in each beaker.

In the first experiment, the eggs were exposed to $\mathrm{pH}$ values of $3,4,5,6,7,8,910,11$ and 12 . To adjust the $\mathrm{pH}$, sodium hydroxide $(\mathrm{NaOH})$ and hydrochloric acid $(\mathrm{HCl})$ solutions were used, drops being added twice a day (at 8:00 a.m. and 6:00 p.m.).

In the second experiment, the eggs were kept at different concentrations of the main ions occurring in freshwater (APHA, 1989).

The salts used and their respective concentrations are given in Table 1.

In the third experiment, carried out in a germination chamber, the eggs were kept at temperatures of $10,15,20,25,30,35$ and $40 \pm 1{ }^{\circ} \mathrm{C}$. The light intensity inside the chamber (650 lux with a fluorescent lamp) was similar to that used in the laboratory during experiments 1 and 2 .

In the fourth experiment, the eggs in the germination chamber were submitted to different photoperiods: $0,8,12,16$ and 24 hours light.

The temperature was maintained at $25 \pm 1^{\circ} \mathrm{C}$ and the light intensity, except at 0 photoperiod, at 650 lux.

TABLE 1

The types and concentrations of salts used in experiment 2. In addition, deionized water was tested.

\begin{tabular}{|l|c|c|c|c|}
\hline \multirow{2}{*}{ Water type } & \multicolumn{4}{c|}{ Concentration of salts used (mg. $\mathbf{L}^{-\mathbf{1}}$ ) } \\
\cline { 2 - 5 } & $\mathbf{N a H C O}_{\mathbf{3}}$ & $\mathbf{C a S O}_{\mathbf{4}} \cdot \mathbf{2 H}_{\mathbf{2}} \mathbf{O}$ & $\mathbf{M g S O}_{\mathbf{4}}$ & KCl \\
\hline Very soft & 12.0 & 7.5 & 7.5 & 0.5 \\
\hline Soft & 48.0 & 30.0 & 30.0 & 2.0 \\
\hline Moderately hard & 96.0 & 60.0 & 60.0 & 4.0 \\
\hline Hard & 192.0 & 120.0 & 120.0 & 8.0 \\
\hline Very hard & 384.0 & 240.0 & 240.0 & 16.0 \\
\hline
\end{tabular}


In the fifth experiment, carried out in a germination chamber, the eggs were submitted to different light intensities: 0, 650, 850, 1,350 and 2,000 lux. The temperature was kept at $25 \pm 1^{\circ} \mathrm{C}$ and the photoperiod at 12 hours, except for the treatment in which the eggs were kept in the dark.

Each experiment was replicated, while each treatment of each experiment had ten repetitions, using ten eggs in each.

For each experimental replicate, all eggs used were produced by the same population and at the same period. The data were examined using Analysis of Variance (ANOVA), experimental replicates being combined; treatment means were compared with the Tukey complementary test (Pimentel-Gomes, 1985).

\section{RESULTS}

Ephippia had an average size of 458.11 (S.D. $27.79) \times 287.48$ (S.D. 19.49) $\mu \mathrm{m}(\mathrm{n}=100)$.

Ephippial egg hatching occurred within a wide range of $\mathrm{pH}$ values (Fig. 1). There were no significant differences $\left(\Delta_{\text {Tukey }}=1,503 ; \mathrm{p}<0.05\right)$ in the range of $\mathrm{pH} 5$ to 9 . Some hatching occurred at extreme $\mathrm{pH}$ values: $1 \%$ at $\mathrm{pH} 12$ and $4.5 \%$ at $\mathrm{pH} 3$.

With regard to the different ionic concentrations, there were no significant differences ( $p>0.05)$ among the treatment's. The $\mathrm{pH}$ variation between the six treatments was not great; however, conductivity showed considerable variation (Table 2 ).

Considering temperature (Fig. 2), hatching occurred within a wide range $\left(15\right.$ to $\left.40^{\circ} \mathrm{C}\right)$.

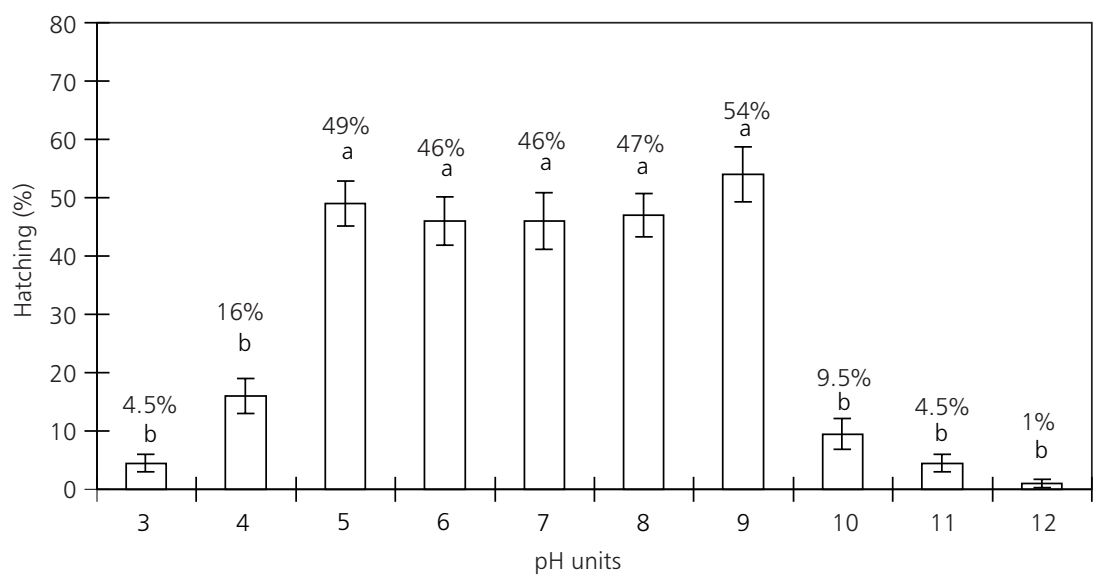

Fig. 1 - Hatching rates (means and standard errors) of $M$. micrura ephippial eggs at different $\mathrm{pH}$ values. The letters a and $\mathrm{b}$ indicate means which did not differ significantly.

TABLE 2

Hatching rates (means and standard errors) of M. micrura ephippial eggs submitted to different water ionic concentrations (experiment 2 ). Ranges of $\mathbf{p H}$ and conductivity values during the experiment are given.

\begin{tabular}{|l|c|c|c|c|}
\hline \multicolumn{1}{|c|}{ Water type } & $\begin{array}{c}\text { Total } \\
\text { hatching } \\
(\boldsymbol{\%})\end{array}$ & $\begin{array}{c}\text { Standard } \\
\text { errors } \\
( \pm)\end{array}$ & $\begin{array}{c}\text { PH } \\
\text { variation }\end{array}$ & $\begin{array}{c}\text { Conductivity variation } \\
\left(\mu \mathbf{S . c m}^{-1}\right)\end{array}$ \\
\hline Deionized & 32.5 & 3.23 & $6.63-8.56$ & $3-15$ \\
\hline Very soft & 38.0 & 4.51 & $6.52-7.65$ & $32-45$ \\
\hline Soft & 34.0 & 2.34 & $6.48-8.16$ & $116-143$ \\
\hline Moderately hard & 29.5 & 3.73 & $6.84-8.56$ & $150-354$ \\
\hline Hard & 33.0 & 3.71 & $7.30-8.67$ & $243-617$ \\
\hline Very hard & 28.0 & 3.04 & $7.70-8.87$ & $425-994$ \\
\hline
\end{tabular}


The $25^{\circ} \mathrm{C}$ treatment was significantly different from the others $\left(\Delta_{\text {Tukey }}=0.989 ; \mathrm{p}<0.05\right)$ and resulted in the best hatching (76\%). A reasonable result was also achieved at the temperature of $20^{\circ} \mathrm{C}$ ( $49 \%$ of hatching).

Hatching was considerably reduced at the extreme temperature of $40^{\circ} \mathrm{C}(2 \%$ of hatching). There was no significant difference in the hatching of eggs exposed to different photoperiods varying from 8 to 24 hours or light intensities varying from 850 to 2,000 lux (Table 3). Hatching was almost nonexistent in the dark in both experiments.

\section{DISCUSSION}

With the procedure used in feeding $M . m i$ crura, we have tried to eliminate the possibility that the diet might be influencing the feasibility of the ephippia since, with the organisms being sufficiently well feed, they should have generate energetically rich eggs.

TABLE 3

Hatching rates (means and standard errors) of $M$. micrura ephippial eggs submitted to different photoperiods and light intensities (experiments 4 and 5). For each experiment, means which did not differ significantly are indicated by the same letter.

\begin{tabular}{|c|c|c|c|c|c|c|c|c|}
\hline \multirow{2}{*}{$\begin{array}{l}\text { Photo- } \\
\text { period } \\
\text { (hours) }\end{array}$} & \multirow{2}{*}{$\begin{array}{c}\text { Light } \\
\text { intensity } \\
\text { (lux) }\end{array}$} & \multicolumn{6}{|c|}{ Hatching (\%) } & \multirow{2}{*}{$\begin{array}{l}\text { Standard } \\
\text { errors }( \pm)\end{array}$} \\
\hline & & $3^{\text {rd day }}$ & $4^{\text {th }}$ day & $5^{\text {th }}$ day & $6^{\text {th }}$ day & $7^{\text {th }}$ day & Total* & \\
\hline 0 & 0 & 0.5 & 0.5 & 1.5 & 0.5 & 0 & $3.0 \mathrm{~b}$ & 1.05 \\
\hline 8 & 650 & 1.0 & 36.0 & 18.5 & 2.0 & 0.5 & $58.0 \mathrm{a}$ & 2.96 \\
\hline 12 & 650 & 17.5 & 31.0 & 5.5 & 2.5 & 0 & $56.5 \mathrm{a}$ & 2.09 \\
\hline 16 & 650 & 21.0 & 34.5 & 2.0 & 0 & 0 & $57.5 \mathrm{a}$ & 4.28 \\
\hline 24 & 650 & 18.5 & 22.0 & 15.5 & 4.0 & 6.5 & $66.5 \mathrm{a}$ & 3.58 \\
\hline 0 & 0 & 0 & 0.5 & 1.0 & 1.0 & 0 & $2.5 \mathrm{c}$ & 0.99 \\
\hline 12 & 650 & 0 & 13.0 & 31.5 & 2.0 & 0 & $46.5 \mathrm{~b}$ & 2.74 \\
\hline 12 & 850 & 0 & 15.0 & 36.0 & 5.5 & 0 & $57.5 a b$ & 2.80 \\
\hline 12 & 1,350 & 0 & 11.0 & 32.5 & 11.5 & 5.0 & $60.0 \mathrm{a}$ & 4.23 \\
\hline 12 & 2,000 & 0 & 38.5 & 13.0 & 5.5 & 3.0 & $60.0 \mathrm{a}$ & 3.32 \\
\hline
\end{tabular}

* Photoperiod: $\Delta_{\text {Tukey }}=1,188 ; \mathrm{p}<0.05$.

Light intensity: $\Delta_{\text {Tukey }}=1,187 ; \mathrm{p}<0.05$.

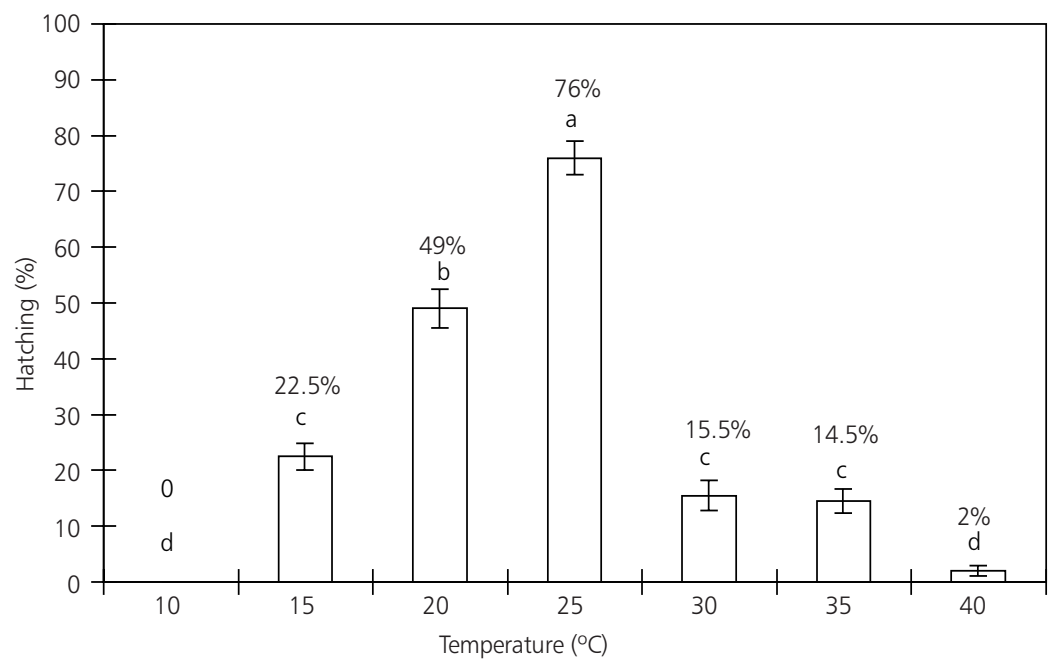

Fig. 2 - Hatching rates (means and standard errors) of $M$. micrura ephippial eggs at different temperatures. The letters indicate means which did not differ significantly. 
The production of ephippia by the $M$. micrura populations was apparently spontaneous and occurred synchronously for short periods of time. Different egg production induction factors have been tested by us (water temperature, photoperiod, light intensity, quality and quantity of food, and parental stage), but the positive results were sporadic and it has not been possible to identify a single factor which might effectively induce the production of these eggs. In practice, the populations were kept in aquaria until they commenced intense and synchronous ephippial production. The period between one bout of ephippial production and another was never the same. Future work should be directed towards identifying the factors inducing the production of cladoceran ephippia in tropical regions. The lack of knowledge of such factors has been one of the major difficulties in carrying out the present study.

In none of the experiments did the hatching rate approach $100 \%$, as has been found for other crustaceans (Davison, 1969; Sorgeloos et al., 1986). This fact might be related to an intrinsic characteristic of the species, but could also be due to differences in the hatching techniques employed.

\section{The effect of $\mathrm{pH}$}

Since the water used in the experiments was not replaced during the seven days of experimentation, no abrupt $\mathrm{pH}$ and conductivity variations took place, thus exposing the eggs to $\mathrm{pH}$ values close to the ones planned for each treatment. The greatest differences among $\mathrm{pH}$ values in all containers of a particular treatment were between 1.0 and 1.5 unit. Due to this variation, the term "egg exposition" instead of "egg maintenance" was used for the different $\mathrm{pH}$ values. The "maintenance" of eggs at a set $\mathrm{pH}$ value would require the use of an appropriate buffer, which would introduce other variations in the environment, such as in the salt content.

Sato (1967, apud Sorgeloos et al., 1986) pointed out that, after breaking through the Artemia cyst shell, the embryo enters in direct contact with the outside environment through the hatching membrane and, at this moment, the ionic composition of the hatching environment should be similar to that of sea water, with $\mathrm{pH}$ between 8 and 9 for a hatching around $100 \%$. Thus, it seems that the $\mathrm{pH}$ tolerance of $M$. micrura embryos (maximum hatching bet- ween $\mathrm{pH}$ values of 5 and 9) is greater than that seen for Artemia.

The hatching of the M. micrura eggs at extreme $\mathrm{pH}$ values shows that they might be capable, when present in the sediment of fish ponds, of resisting the liming processes, usually used in aquaculture, and which cause great $\mathrm{pH}$ variations, and the large $\mathrm{pH}$ fluctuations which can occur on a daily basis in such ponds, thereby remaining viable and producing young to recolonize the environment.

\section{Ionic concentration}

As it was found in experiment 1 that $M$. micrura eggs satisfactorily hatched in the $\mathrm{pH}$ range of 5 to 9 , the differences among $\mathrm{pH}$ values experienced in the present experiment probably did not influence the results achieved. Similarly, in relation to the conductivity variation, it may be seen that the ephippial eggs hatched in a wide range of this factor (Table 2).

During attempts by us at cultivating M. micrura, some culture media recommended for Cladocera (D’Agostino \& Provasoli, 1970; Conklin \& Provasoli, 1977) were used. These procedures have not given satisfactory results, probably because they were originally developed for populations from temperate regions in the northern hemisphere where, in general, waters have greater ionic concentrations. It was therefore of interest to examine the effects of different ionic concentrations on the hatching success of ephippial eggs of a warm-water cladoceran population. Despite the absence of significant differences among the treatment results, the organisms which hatched in very soft and soft waters showed greater activity. In the treatments with hard and very hard waters, the organisms presented, following birth, an apparently normal behavior but, when left in the hatching container, they died after a few hours. Further research on the sensitivity of $M$. micrura to total ionic concentration and the concentration of particular ions in the water would be of interest.

For the experiments with temperature, photoperiod and light intensity, the $\mathrm{pH}$ was near neutrality (6 to 8), and conductivity was similar to the treatments of very soft and soft waters as defined in experiment 2 (32 to $143 \mu \mathrm{S} . \mathrm{cm}^{-1}$ ). These $\mathrm{pH}$ and conductivity variations belong within the main not significantly different groupings of experiments 1 and 2 and, therefore, they probably did not affect the results obtained. 


\section{Temperature}

Davison (1969) obtained 100\% hatching of decapsulated eggs of Daphnia pulex at temperatures of $24^{\circ} \mathrm{C}$ or lower, whereas at $30^{\circ} \mathrm{C}$, only $20 \%$ of the embryos completed their development. For Artemia sp., Sorgeloos et al. (1986) recommended that the temperature for egg hatching should be kept constant between 25 to $30^{\circ} \mathrm{C}$, since below this range hatching is slower and, above it, energy losses occur due to the embryo's accelerated metabolism. In the present study, egg hatching was sensitive to temperature variation, especially at the highest values, where a noticeable reduction in hatching took place. However, the hatching rate of $2 \%$ at a temperature of $40^{\circ} \mathrm{C}$ shows the capacity of these eggs to resist the high temperatures, which can occur in fish ponds in tropical regions.

\section{Light}

For Daphnia, Stross $(1966,1969)$ noted that the methodology used for stocking eggs (low temperatures for a few weeks) was more important for obtaining better hatching results than the use of different photoperiods and light intensities. Stross (1971) used, for D. pulex eggs, lighting pulses at different hatching stages, and noted that the best results occurred with an initial 16-hour light pulse, followed by a period of darkness ( $72 \%$ of hatching), or with two 2-hour pulses: an initial one and another from the $14^{\text {th }}$ to the $16^{\text {th }}$ hour of the experiment (63.6\% of hatching). Davison (1969) stated that $D$. pulex ephippia require a light intensity of 418 lux for $100 \%$ activation, due to the "shell" protection provided to the embryo. For Artemia sp. cysts, Sorgeloos et al. (1986) compared the hatching of four lots of eggs from different regions at light intensities of 20, 100, 1,000 and 2,000 lux; they found that a minimum light intensity of 2,000 lux, using either natural or artificial light, was essential to obtain maximum hatching (100\%), at least in the first hours of cyst hydration.

In the present study, the hatching of $M$. $m i$ crura ephippia was strongly affected both by the photoperiod and the light intensity. In relation to the number of days required for hatching, it was not possible to correlate photoperiod with the length of time for the greatest hatching (Table 3). However, with regard to light intensity, it was found that, in the treatment of 2,000 lux, there was a tendency for egg hatching to occur in a shorter period of time. The use of light intensities greater than 2,000 lux might offer even better hatching results specially if combined with a photoperiod of 24 hours light.
In summary, optimum conditions for the hatching of ephippial eggs of $M$. micrura were found to involve a water $\mathrm{pH}$ of around neutrality (5-9), and a temperature of $25^{\circ} \mathrm{C}$. Photoperiod and light intensity with a minimum of 8 hours and 850 lux, respectively, were necessary.

Acknowledgments - We thank Dr. Kennedy Francis Roche for his comments on the manuscript and linguistic improvements.

\section{REFERENCES}

AMERICAN PUBLIC HEALTH ASSOCIATION, 1989, Standard methods for the examination of water and wastewate. $17^{\text {th }}$ ed. Ed. American Public Health Association, New York, pp. 8-16.

CONKLIN, D. E. \& PROVASOLI, L., 1977, Nutritional requirements of the water flea Moina macrocopa. Biol. Bull., 152: 337-350.

D’AGOSTINO, A. \& PROVASOLI, L., 1970, Dixenic culture of Daphnia magna Straus. Biol. Bull., 139: 485-494.

DAVISON, J., 1969, Activation of the ephippial egg of Daphnia pulex. J. Gen. Physiol., 53: 562-575.

FREGADOLLI, C. H., 1993, Food selection of pacu Piaractus mesopotamicus Holmberg, 1887 and tambaqui Colossoma macropomum Cuvier, 1818 larvae in the laboratory. B. Tec. CEPTA, 6(1): 1-50 (in Portuguese).

GUILLARD, R. R. L. \& LORENZEN, C. J., 1972, Yellowgreen algae with cholorophyllid-c. J. Phycol., 8: 10-14.

PIMENTEL-GOMES, F., 1985, Experimental statistics. Ed. Nobel, Piracicaba, SP, 466p. (in Portuguese).

ROJAS, N. E. T., 1995, Hatching of Brachionus calyciflorus Pallas, 1776 (Monogononta: Ploima) and Moina micrura Kurz, 1874 (Crustacea: Cladocera) resting eggs induced by abiotic factors. Master's Thesis, UFSCar, São Carlos, 147p. (in Portuguese).

SORGELOOS, P., LAVENS, P., LÉGER, P., TACKAERT, W. \& VERSICHELE, D., 1986, Manual on the cultivation and use of Artemia in aquacultur. Ed. United Nations Organization for Agriculture and Nutrition, Aquila Project Doc. 10, 301p. (in Spanish).

STROSS, R. G., 1966, Light and temperature requirements for diapause development and release in Daphnia. Ecology, 47: 368-374.

STROSS, R. G., 1969, Photoperiod control of diapause in Daphnia. III Two stimulus control of long-day, shortday induction. Biol. Bull., 137: 359-374.

STROSS, R. G., 1971, Photoperiod control of diapause in Daphnia. IV Light and $\mathrm{CO}_{2}$ - sensitive phases within the cycle of activation. Biol. Bull., 140: 137-155.

ZANIBONI FILHO, E., 1992, Incubation, larviculture and fingerling production of tambaqui (Colossoma macropomum Cuvier, 1818). Ph.D. Thesis, UFSCar, São Carlos, 202p. (in Portuguese). 